\title{
COMMUNITY BASED MOUNT MERAPI ERUPTION DISASTER MANAGEMENT
}

\author{
Septian Aji Permana ${ }^{1 *}$, Supri Hartanto ${ }^{1}$, Ary Purwatiningsih ${ }^{2}$, Mohamad Maulana Magiman $^{3}$ \\ ${ }^{1}$ Universitas PGRI Yogyakarta, Indonesia \\ 2 Universitas Terbuka, Indonesia \\ 3 Department of Social Science, Faculty of Agriculture and Food Science, Universiti Putra Malaysia Bintulu Campus, Sarawak, \\ Malaysia \\ * Corresponding author e-mail: aji@upy.ac.id
}

\section{ABSTRACT}

Purpose - This research purpose is to analyze society management in manage natural resource that gotten from Merapi eruption and fin ding the economical system based on regional autonomy. Design/methodology/approach - This research used qualitative approach. The informant of this research was Cangkringan society, Cangkringan village employee, and investors. Data collecting technique was done by observation patricianly and structural interview. Data then analyzed by domain analysis technique, taxonomic, competence, and cultural theme. Findings - The research result shows that Cangkringan society has local wisdom in manage economic after Merapi disaster by opening business entity like cooperative. Social implications - The purpose of Cooperative is to give fund to the Cangkringan society to make them become independent and not dependent to foreign investor. With this cooperative, society can manage economic independently based on local wisdom. Originality/value - Cooperative is business entity that manages by society to their own welfare (from society to society).

Keywords: Management, Culture, Natural Resource, Disaster Advances

Article Received: 18 October 2020, Revised: 3 November 2020, Accepted: 24 December 2020

\section{Introduction}

Law Number 32 Year 2004 gives Autonomy authority to Regency / City implied to Village Autonomy. Even this law can not state explicitly about Village Autonomy, but articles in clause 93 until 111 stated clearly the components of that Autonomy in clause 104 where assigned that Village through Village consultative institution has the power to make Village Rules "PERDES" (Barth, 197; Permana, 2017). Futhermore in clause 101 stated that the task and duty of Head Village are lead the organization of Village government, develop village society life and lead the village economic life. Use the "Insert Citation" button to add citations to this document.

The meaning of lead and develop are wider than only take care like in Autonomy meaning (Kesel, 014) ' (Mahoney, 1981) gives illustration that Regional Autonomy implicated to the widest opurtinity for government and society to be together involve in the process of development.

Cangkringan area that is the biggest sand material producer in Indonesia, is good prospect for government or society to manage it better to make society feels the result of its natural resource (Permana, 2017) The real is sand minning in Cangkringan only need low investation rather than other minning in other places. It makes its attractiveness for busnissman. The ability of big investor is stronger economically than local investor who near from the location (Glik, 2014; LEbowitz, 2014; Luo, 2013; Mahoney 1981).

Before 1989, minning is manually by society around ravines and that minning has no legality. During Merapi DAM build, the minning is only for DAM bulid activity until 1991. Start from 1992 begins legality of minning with heavy equipment that published directly by Province government until 1998 (Permana, 2017; Pyles, 2011; Sajogya 1977)

At 1998 begins new episode of minning activity with some miracles at that year like:

1. The biggest minning conflict in the minning history of Sleman Regency, that was buring 14 units of heavy equipment. 
2. The Legality of minning begins be trusted on Regency govenment.

3. Founding of PDAU (Perusahaan Daerah Aneka Usaha) that enganged in the minning level $\mathrm{C}$ business.

4. Beginning of minning activities outside of ravines or around green area and the area of PERHUTANI.

At 1995 born colaboration pruduct of big minning management especially in Cangkringan and survived until 2005. At 2003 publishes Local Law of Minning Number 21 that especially discuss about legality, but this product produced three legatities of minning and 38 busnissmen have no legality until published decree 19 about limitation close minning area with some limitations (Permana, 2017; Sajogya, 1977; Hettige, 201).

At 2005 stopped forign investor operational. At 2007 there were group of minners but the implementation in the field was still difficult. There was people logging permit or IPR (Ijin Pertambangan Rakyat) about $10 \mathrm{Ha}$ in Gendol, Opak, and Kali Adem rivers, for one year. At 2008 founding of Usaha Mandiri Cooperative, in this case was the form of society concern of village recouses and potentions management that so ragged. At 2008 from minning dari division of Usaha Mandiri Cooperative surveied minning activities including minning location, the origin of the miners and material distributors (Prajanti, 2013; Pyles, 2011; Sajogya, 1977; Hettige, 2016).

In line with minning development above, the management of society minning should be :

1. Involving local society as the main subject in taking the benefit.

2. Giving the society authoriy as dicesion making of right busniss system.

3. Inceasing government role as fasilitator and activity monitor.

4. Giving certainty and clarity of rights and obligations to all profesionally.

5. Creating and developing institutional of enterpreanure decided by society.
6. Oncoming of the enterpreanure based on the type of minning material and the diversity culture.

It can be concluded that there are sand and rock minning autonomously to increase welfare, life quality, capability, economic and social capasity of the society. Realizing integrity and sinergity in doing regional development based on ecological, economical and social cultural sustainability. Increasing society community around the minning who had responsibility to keep environmental sustainability and security. Increasing the benefit of natural resources to society interest by guarantee the long environmental sustainability. Increasing the quality of secure productivity around minning and environmental sustainability around it. Pushing and accelerating the development of other sector for reaching local progress and independent. Empowering and increasing publict institutional capacity through micro and medium enterprise cooperative either minning sector or others.

\section{Materials And Methods}

This reseach used qualitative approach. This research was done in Cangkringan district, Yogyakarta. The research subject was Cangkringan society who estimated had knowlegde and understanding about the way of sand minning in there. The informant determination was done by snowball sampling. Data collecting technique insterument was observation (partisipantly, straightforward and implicite and structurally), interview ( used descriptive, structural and contradictive questions), and documentaion. Data analysis technique used domain, taxonomy, componential with organazed process and reduction the data into pattern, categorized and basic description unit cuold decide the theme and could make conclution. Cultural analysis theme was done when data collection and after that. Analysis data that had been done were arranging, sorting, codding and catagorizing the data so it can decide the appropriate.

Results and Discussion 
Cangkringan is distrct in Sleman regency of Yogyakarta. Cangkringan area has its attractiveness because it's place that drained with bigs rivers that produce many sand and rocks like Opak, Gendol, and Kuning rivers. Sand and rock in Cangkringan is from material of Merapi eruption so until nowdays society has perception that Merapi eruption is a gift and not a threat. Geographic location of Cangkringan that has potential to produce sand and rocks so this area can develop as Industrial area (Permana, 2016; Permana, 2017; Eickelman, 1978; Glenn, 2013).

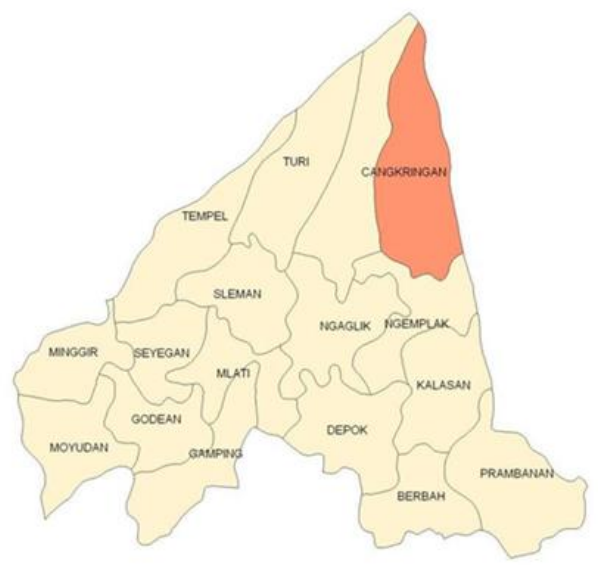

Figure 1. Cangkringan Area Map

Cangkringan has plan village middle development (RPJMDes) to thier society walfare. Village development plan that planed by Cangkringan society to long plan, that is three until five years. This plan development is done by notice the society capability in serving fund and the utilization of natural resource of its development (Bhandari, 2014; Chen 200; Deeg, 2005; Dominelly, 1996)

Realization of independent Cangkringan as the centre of tourism development and barometer in Yogyakarta based on prior econimic, productive and inovative also forward the society role that dinamic, hormony in the savety and controled environtment based on togetherness, unity and entity for all (Permana, 2017; Mahoney, 1981; Hettige, 201).

Cangkringan has plan village middle development (RPJMDes) is guidance and reference for the execution of build that will be done by village government about six years. Therefor, the substantion of it covers the entire matters of village, and covers the entire function that is done by Satuan Kerja Perangkat Daerah (SKPD). In line with the scope of authority of village government, the strategy that will be used by Village government around Cangkringan Sub-district at 2014-2020 covers 3 (three) main agendas, that are : (1) Realizing good village government; (2) Increasing the quality of society life; and (3) Increasing society autonomy. Those three agendas will realized through village development strategy that autonomy. Strategy is a technique to realize the goal that created conceptually, analitically, realistically, rationally, and comprehensively (Deeg; 2005, Prajanti; 2013). Strategy is realized in policy and program. Policy is the way that taken by village government in deciding program conviguration form and activities to reach the goal (Pyles, 2011; Sajogya, 1977; Permana, 2017).

Resource and job of Cangkringan societies (Argomulyo, Glagahharjo, Kepuharjo, Umbulharjo, and Wukisari Village) because near from Merapi mountain has high level of fertility because of the volcano ash from the mountain (Pyles, 2011)

There are some potention of natural resource :

1. Beautiful nature of mountain and river/ hills in Cangkringan

2. High fertile land and compatible for agriculture

3. Minning material of sand and rocks

4. Drained some rivers in each village (Kuning, Opak, Adem, and Gendol Rivers)

5. Plantation like coffee, cacao, and vanily become plant priority

6. Farming (dairy cow, beef catel, chicken, goat, rabbit) that has many effects in increasing economic (Permana, 2017; Setyowati, 2014; Smith, 1977)

The superior comodity of Cangkringan district is sand and rocks. The resource of sand and rocks material are from Kali Kuning, Kali Opak, Kali Adem, and Kali gendol. Although Merapi brings threat but for the society it is a gift because many of them depend on the nature (Merapi) (Permana, 2017; Pranjanti, 2013; Pyles, 2011). 


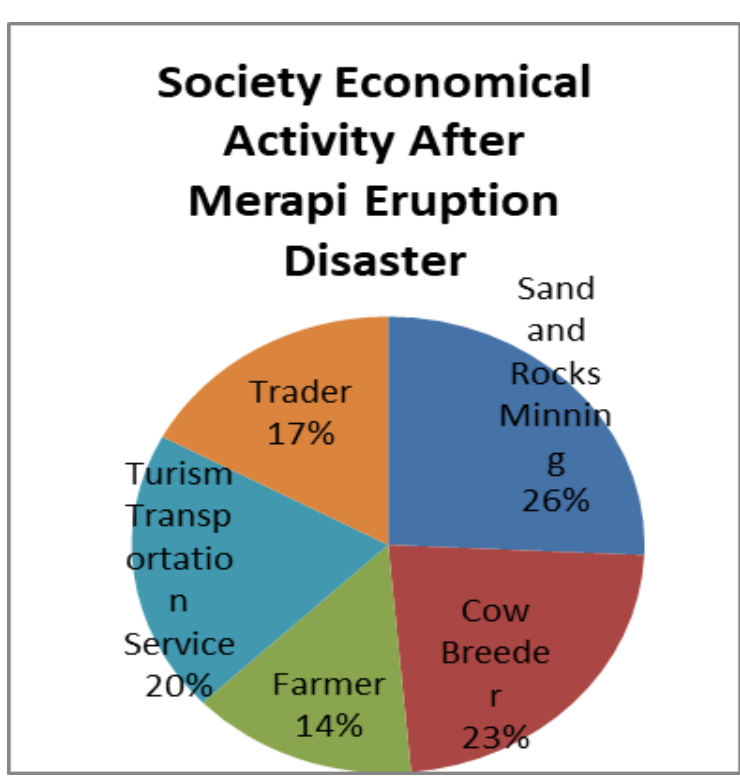

Figure 2. Economical Activity of Cangkringan Society

Many economical activities after Merapi eruption has been change that are the society prefer to do sand and rocks minning. Economical activities like seling, developing lava tour turism and husbandry and farming that become main comodity are still maintained. Bised that some of them appointed as abdidalem (court employees) of Yogyakarta Palace as form of their devotion (Kasdan, 2016; Kessel, 2014; Permana, 2016).

From the economical point of view, Cangkringan area is the centre of many activities in the hills in seeking livelihood covers tourism, trading, farming, sand and rocks minning. This cannot regardless of the position of research place to other places surrounding it, so Cangkringan district is relatively has better economical condition. Beside that, Cangkringan has road access that connected Yogyakarta city with Kaliadem and Larva Tour Tourism that easier the tourist to come there. This condition is open challange to Cangkringan society to do many activities whether inside or outside the district (Helibroner, 1976; Kamp, 2005; Permana, 2016)

Cangkringan society depend his life from many jobs. The kind of their jobs are cow breeder, salak plantation, and farming. Other that, they also have some businesses like opening grocery store to fullfill their need or turist around Kaliadem or lava
Tour and as lobor of sand and rocks minning in dry season (Pyles, 2011).

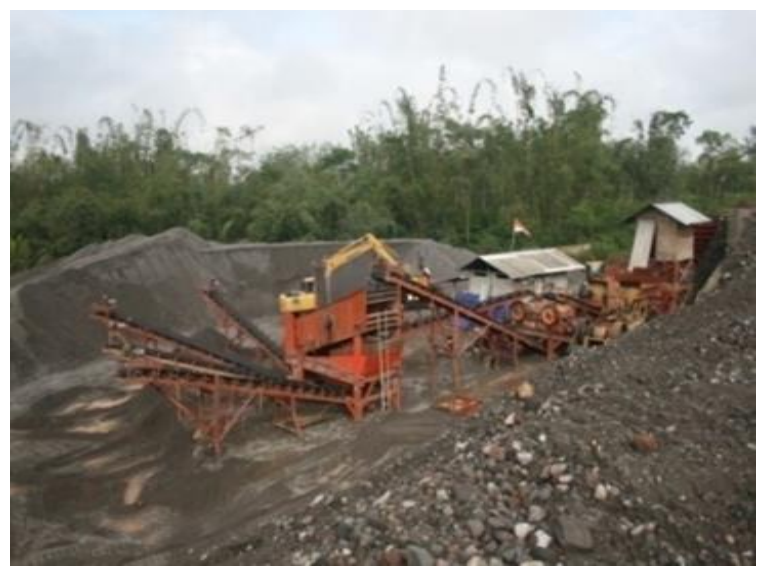

Figure 3. The Rocks Minning Place as Raw Material of Block Making in Umbulharjo, Cangkringan

Local material availability in Cangkringan can fulfill the need of material for local society.This eruption materials then collected by society then they make it as block, mortar, and materials for plaster floor. Many of local material like big rock, small rock and sand are from Merapi eruption, collected by society as local material business whether in the raw form or mature form, like block, roaster and etc (Permana,2017).

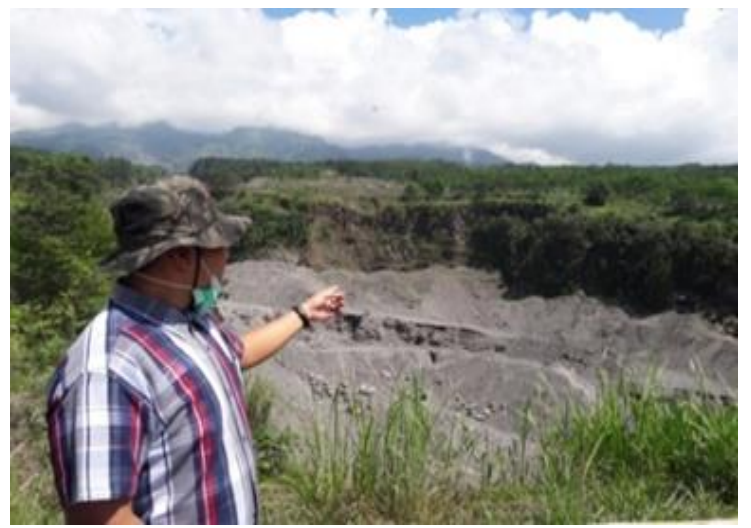

Figure 4. Parennial Sand Dunes in Desa Petung, Cangkringan

The distribution of sand material uses transportation vehicle like sand minning truck and the material takes from Opak, Gendol, and Elo river. This distribution of this materials has function to connect producent with consumen. The minning is totally done by society, heavy 
equipments because can demage the road and environment. The entire material manage by society also the result (Permana, 2017).

Beside they becomes sand and rocks manner, they also become bredeer, especially dairy cow and beef cattle. Then, they also sale the milk that collected by local village cooperative (KUD) with price Rp. $2000,-$ per liter. In one day they can supply two times with the average in each supply is 5-10 liter per (Pyles, 2011; Sajogya, 1977; Setyowati, 2014).

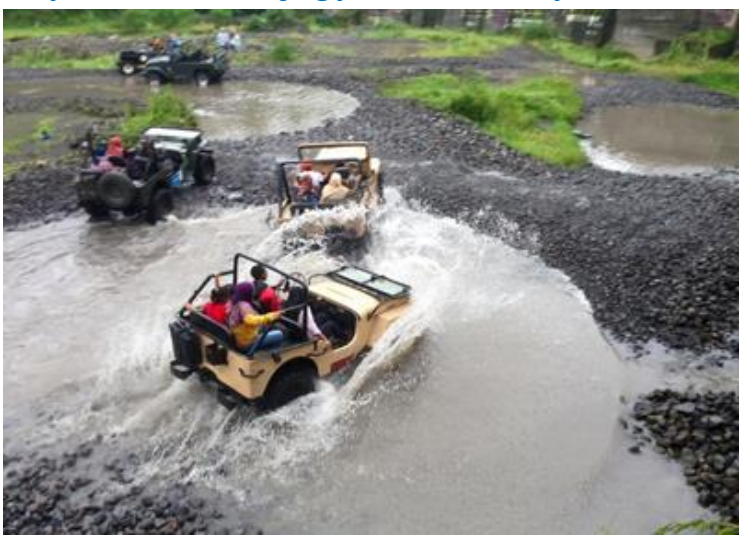

Figure 5. Business of Jeep Lava Tour Turism

Tourism development in Cangkringan from year to year is also increase rappidly and society interest and awareness. Tourism industry is more develop in natural concept like Lava tour turism where the turist just need 350-550 rupiah. They can go around to enjoy the beautiful nature and rest building of Merapi eruption. Remember at 2010 Cangkringan society had job as farmer and bredeer, because of the eruption, they change their job as trader (Chen, 2006; David, 2016).

The area that rich of natural resources makes society become stubborn to evacuate when Merapi eruption comes because for them it is a gift. It is a real prove of social wisdom to always life earthy with nature. Although they are in susceptible area but they still do daily activities (Deeg, 2005; Dominelly, 1996).

Based on Cangkringan society who reluctant to leave their area, more feel it as a common thing, it is beacuse their existency as mountain society who has environment wisdom that can life together with nature harmoniously. This local wisdom is rather dificult to separate beacuse although they affraid but they also hope it (Permana, 2019).

In life, Javanese society always want harmonity with mindset and life with mutual respect in a society that tied by norms beacause of history, tradition, or religion. Javanese culture has been rooted many years and ingrained. Their attitude has own identity fortified by advices hereditaruy from their ancient so it still life until now in the modern era (Permanan, 2017).

Keep Merapi Montain harmonity, also reflected when the eruption at 2010, whether in Kinahrejo, dusun Pelemsari, desa Umbulharjo, desa Purwobinangun, dusun Turgo, desa Kepulharjo, or dusun Kaliadem. Their believe of nature harmonity can be seen from their attitude that do not want to leave their places although destroy by fire of hot clouds and became forbiden places and uninhabitable. this phenomenon can be understood as a life's attitude to be always harmony with environtmen and nature. They assume that this is their homeland, so Merapi mountain with its natural process, feel as something soulless.

"Merapi peak can split, the thunder sound because avalanches and magma insistence also heard, but the society around Merapi slope like Turgo, Srumbung or Kinahrejo are still calm. They still do their daily activities like sod or searching wood in the forest near Merapi. "If only small thunder, it is common. We are still calm, still sod and searching wood. I still belive Merapi has no clues to eruption, the animals also do not down yet." said Mr. Imam, Pelemsari people, Cangkringan, Sunday, August 02, 2019, at 16.00, in Mr. Imam's house,

Cangkringan society statement who live in the eruption area. Until now, their opinion is still same, that Merapi is a gift beacuse it brings natural resource that can be used to fulfill their need. The society do not want to relocation is a real prove of local wisdom.

Although the society was in evacuation but their daily activities still run. Their unwilling to leave their place, based on Yogyakarta society ponit of view feels as something natural. It is because related with their exixtency as Merapi mountain 
society who cultured, who can life harmonis with nature. This local wisdom is rather dificult to separate beacuse although they affraid but they also hope it (Pyles, 2011).

\section{Conclusions}

Merapi mountain is one of active volcano in Indonesia that produce many minerals in the form of sand and rocks through memproduksi banyak mineral berupa pasir dan batu melalui pyroclastic flows and lava. Because of its quality material, sand minning become one of the main industry around Merapi mountain.

During the process of sand minning is done in the right way, this can promise continuity income and the risk of disaster can be decrease. on the other hand, if the process of sand minning is done in the wrong way, the quality pof life will decrease by many problems like depletion of water sources, sand sources, bridge demage or sabo dam. The sand minning which is based on the right rule have to be done so can inheriting walfare and healty environment to the future generation. The awareness of right sand minning method based on deal from many discussion of related parties with building business entities with legal status.

Since 2006 rises some idies to creat business entity in the form of ccoperative outside of government that accommodates the things outside village government's main jobs, so at 2008 is formed a business entity that has vision and mision manages resources and potention fairly and wisely also continuely to increase Cangkringan society's welfare in the case of publict partisipation in bulding district.

Cangkringan society has been build a business entity in the form of cooperative that is indipendent business cooperative, to be a palce of Cangkringan village businesses. Nowaday that cooperative is not only handle the problem of sand and rocks minning but also wider in turism and micro marketing like provide minimarket to meet. This is as the form of saving and load that legalize inforn of Notary public and the office at Cangkrinfan Subdistrict.
Acknowledgments

The authors would like to thank for the Center of Research and Community Service of Universitas PGRI Yogyakarta (LPPM UPY) and AJIB Team.

\section{References}

[1] Barth, F. (1967). Economic Spheres in Darfur. London: Tavictock

[2] Bhandari R.K. (2014). Disaster Education and Management A Joyride for Students, Teachers, and Disaster Managers. Jurnal: Springer New Delhi Heidelberg New York Dordrecht London 2014, DOI 10.1007/978-81-322-1566-0.

[3] Chen, L. C., Liu, Y. C., \& Chan, K. C. (2006). Integrated community-based disaster management program in Taiwan: a case study of Shang-An village. Natural Hazards, 37(1-2), 209.DOI 10.1007/s11069-005-4669-5.

[4] Shreve, C., Davis, B., \& Fordham, M. (2016). Integrating animal disease epidemics into disaster risk management. Disaster Prevention and Management.http://dx.doi.org/10.1108/DP M-02-2016-0026.

[5] Held, D., \& McGrew, A. (2007).The Global Transformations: A Reader. Cambridge: Polity Press.

[6] Kasdan, D. O. (2016). Considering sociocultural factors of disaster risk management. Disaster Prevention and Management.http://dx.doi.org/10.1108/DP M-01-2016-0008.

[7] Deeg, D. J., Huizink, A. C., Comijs, H. C., \& Smid, T. (2005). Disaster and associated changes in physical and mental health in older residents. The European Journal of Public Health, 15(2), 170-174. https://doi.org/10.1093/eurpub/cki126

[8] Dominelly, L. dan A. Hoogvelts. (1996). "Globalisation and The Technocratisation of Social Work". Critical Social Policy.

[9] Eickelman, Dele F. (1978). The Political Economy of Meaning. American Etnologist 
[10] Fernandez, G., \& Shaw, R. (2013). Youth Council participation in disaster risk reduction in Infanta and Makati, Philippines: A policy review. International Journal of Disaster Risk Science, 4(3), 126136. Doi:10.1007/s13753-013-0014-X.

[11] Glik, D. C., Eisenman, D. P., Zhou, Q., Tseng, C. H., \& Asch, S. M. (2014). Using the Precaution Adoption Process model to describe a disaster preparedness intervention among low-income Latinos. Health education research, 29(2), 272-283.

https://doi.org/10.1093/her/cyt109

[12] Heilbroner, R. L. (1976). Business civilization in decline. Norton.

[13] Held, D. (1995). Democracy and the global order: From the modern state to cosmopolitan governance. Stanford University Press.

[14] Van Kamp, I., Van der Velden, P. G., Stellato, R. K., Roorda, J., Van Loon, J., Kleber, R. J., ... \& Lebret, E. (2006). Physical and mental health shortly after a disaster: first results from the Enschede firework disaster study. The European Journal of Public Health, 16(3), 252-258. Doi:10.1093.

[15] Kasdan, D. O. (2016). Considering sociocultural factors of disaster risk management. Disaster Prevention and Management.

http://dx.doi.org/10.1108/DPM-01-20160008 .

[16] Van Kessel, G., Gibbs, L., \& MacDougall, C. (2014). Strategies to enhance reselience post-natural disaster: a qualitative study of experiences with Australian floods and fres. Jurnal: Journal of Public Health, pp. 1-9, Doi:10.1093/pubmed/fdu051.

[17] Korten, D. (1997). When Corporations Rule The World (Bila Korporasi Menguasai Dunia). Jakarta: Professional Books.
[18] Lebowitz, A. J. (2014). Community Collaboration as a Disaster Mental Health Competency: A Systematic Literature Review. Jurnal: Jurnal Springer Science+Business Media New York 2014, DOI 10.1007/s10597-014-9751-6.

[19] Luo Xiaofeng and Levi Annette. (2013). Factors influencing willingness to participate in disaster reduction. Jurnal: Springer Science+Business Media Dordrecht 2013, DOI 10.1007/s11069-012-0546-1.

[20] Mahoney, T. (1981). Local Political and Economikal Structure. Boulder: Westview Press.

[21] Marshall, T. H. (1981). The Right To Welfare. London: Heinemann.

[22] Mayo, M. (1998). "Community Work", dalam Adams, Dominelli dan Payne (eds), Social Work: Themes, Issues and Critical Debates, London: McMillan.

[23] Menghan,T. (2014). Game-based education for disaster prevention. Jurnal : Springe DOI 10.1007/978-4-431-55090-7.

[24] Mishra, R. (1999). Globalizationa and The Welfare State. Cheltenham: Edward Elgar

[25] Moedjanto., G. (1986). The Concept of Power in Javanes Culture. Yogyakarta: Gajah Mada University Press.

[26] Mulligan, M., \& Nadarajah, Y. (2012). Rebuilding community in the wake of disaster: lessons from the recovery from the 2004 tsunami in Sri Lanka and India. Community Development Journal, 47(3), 353-368. Doi:10.1093/cdj/bsr025.

[27] Oikawa Yukihiko dan Shaw Rajib. (2014). Education for Sustainable Development and Disaster Risk Reduction. Jurnal: Springer Tokyo Heidelberg New York Dordrecht London 2014, DOI 10.1007/978-4-431-55090-7.

[28] Jagdish, P., \& Devnarayan, P. (2019). Role of FDI in the process of Economic Development. Advances in Management, 12(1), 1-3. 
[29] Permana, S. A. (2016). Petuah Merapi Sebagai Kearifan Masyarakat untuk Kesiapsiagaan Menghadapi Ancaman Bencana Erupsi Gunung Merapi di Wilayah Cangkringan, Yogyakarta. Draf Disertasi, UNNES.

[30] Permana, S. A., Dian, S., Prajanti, W., \& Setyowati, D. L. (2016). JTC" Management In Disaster Information System. Ponte Int. J. Sci. Res, 72. http://dx.doi.org/ 10.21506 / j.ponte.2016.12.51.

[31] Permana, S. A., Setyowati, D. L., \& Slamet, A. (2016). SOCIETY IN WISDOM TO KNOW THE SIGNS DISASTER IN THE ERUPTION MERAPI CANGKRINGAN, SLEMAN, YOGYAKARTA.

[32] Permana, S. A., Setyowati, D. L., \& Slamet, A. (2016). THE WISDOM OF MBAH MARIDJAN AS A CARETAKER IN MERAPI THREATS FACING THE MERAPI ERUPTION IN THE CANGKRINGAN, SLEMAN, YOGYAKARTA.

[33] Permana, S.A., D.L. Setyowati., A. Slamet., dan Juhadi. (2017). Bencana dan Anugerah. Yogyakarta: Graha Ilmu

[34] Permana, S.A., D.L. Setyowati., A. Slamet., dan Juhadi. (2017). Community Ritual in Dealing With the Threat of Merapi Eruption. Internasional Journal of Indonesia Society and Culture. Vol.9, No.1. ISSN: 2086-5464. http://journal.unnes.ac.id/nju/index.php/ko munitas

[35] Permana, S.A., D.L. Setyowati., A. Slamet., dan Juhadi. (2017). Panduan Pendidikan Kebencanaan Berbasis Petuah Merapi. Yogyakarta: Graha Ilmu

[36] Permana, S.A., D.L. Setyowati., A. Slamet., dan Juhadi. (2017). Society Management In Manage Economic After Merapi Disaster. Internasional Journal of Applied Business and Economic Research. Vol.15.No.6.2017. ISSN:

0972-7302,

http://www.serialsjoaurnal.com.
[37] Prajanti, Sucihatiningsuh Dian Wisika. (2013). Evolution On Benefits And Development of Information and Communication Technology (ICT) To Improve The Perfomance Of Agricultur Extension In Sentral Java. Internasional Journal. Organization Innovation (Online) $6.2 \quad$ (Oct 2013) 243-253. https://worldresearchersassociations.com/ mngmntspecialissue/1.pdf

[38] Pyles, L. (2011). Neoliberalism, INGO practices and sustainable disaster recovery: A post-Katrina case study. Community Development Journal,46(2), 168-180. Doi:10.1093/cdj/bsp058

[39] Sajogya. (1977). Garis Kemiskinan dan Kebutuhan Minimum Pangan. Jakarta: Kompas

[40] Setyowati, D. L. (2014). Public Perception of Disaster Landslides and Efforts to Overcome in Subdistrict Kaloran Central Java. Universal Journal of Geoscience, 2(7), 195-199.

[41] Hettige, S., \& Haigh, R. (2016). An integrated social response to disasters: the case of the Indian Ocean tsunami in Sri Lanka. Disaster Prevention and Management: An International Journal. https://doi.org/10.1108/DPM-11-20150263

[42] Smith, W. (1977). The Fiesta Sytem and Economic Change. New York: Columbia University Press.

[43] Zhang, X., Yi, L., \& Zhao, D. (2013). Community-based disaster management: a review of progress in China. Natural Hazards, 65(3), 2215-2239. DOI 10.1007/s11069-012-0471-3

[44] Yen lien Chin, Loh Siung Chin, Chen Chun Lian, Wei Liangyung, Lee Wencheng, and Ho Hsinya. (2006). Development and Implementation of Disaster Reduction Technology in Taiwan. Jurnal: SpringeVerlag London 2006, DOI 10.1007/s11069-005-4652-1. 
[45] Yzermans, C. J., Donker, G. A., Kerssens, J. J., Dirkzwager, A. J., Soeteman, R. J., \& Ten Veen, P. M. (2005). Health problems of victims before and after disaster: a longitudinal study in general practice. International Journal of Epidemiology, 34(4), 820826.Doi:10.1093/ije/dyi096. 